\title{
Considerations in the development of circulating tumor cell technology for clinical use
}

\author{
David R Parkinson ${ }^{1 *}$, Nicholas Dracopoli ${ }^{2}$, Brenda Gumbs Petty ${ }^{3}$, Carolyn Compton ${ }^{4}$, Massimo Cristofanilli ${ }^{5}$, \\ Albert Deisseroth ${ }^{6}$, Daniel F Hayes ${ }^{7}$, Gordon Kapke ${ }^{8}$, Prasanna Kumar ${ }^{9}$, Jerry SH Lee ${ }^{10}$, Minetta C Liu ${ }^{11}$, \\ Robert McCormack ${ }^{12}$, Stanislaw Mikulski ${ }^{13}$, Larry Nagahara ${ }^{10}$, Klaus Pantel $^{14}$, Sonia Pearson-White ${ }^{15}$, \\ Elizabeth A Punnoose ${ }^{16}$, Lori T Roadcap ${ }^{17}$, Andrew E Schade ${ }^{18}$, Howard I Scher ${ }^{19}$, Caroline C Sigman ${ }^{3}$ and \\ Gary J Kelloff ${ }^{10}$
}

\begin{abstract}
This manuscript summarizes current thinking on the value and promise of evolving circulating tumor cell (CTC) technologies for cancer patient diagnosis, prognosis, and response to therapy, as well as accelerating oncologic drug development. Moving forward requires the application of the classic steps in biomarker development-analytical and clinical validation and clinical qualification for specific contexts of use. To that end, this review describes methods for interactive comparisons of proprietary new technologies, clinical trial designs, a clinical validation qualification strategy, and an approach for effectively carrying out this work through a public-private partnership that includes test developers, drug developers, clinical trialists, the US Food \& Drug Administration (FDA) and the US National Cancer Institute (NCl).
\end{abstract}

Keywords: Circulating tumor cells, Prognostic biomarker, Predictive biomarker, Analytical validation, Clinical validation, Biomarker qualification, Oncologic drug development

\section{Introduction}

The Foundation for the National Institutes of Health (FNIH) Biomarkers Consortium is a public-private biomedical research partnership that promotes the development and qualification of promising biomarkers for the prevention, early detection, diagnosis and treatment of disease. Consortium partners include patient advocates, clinical researchers from academia and industry, industry members from both therapeutic and diagnostic industries, the NCI, and the FDA. The Cancer Steering Committee (CSC) of the Biomarker Consortium focuses specifically on research activities to further improve treatment for patients with cancer through the use of biomarkers in drug development and in the field of personalized medicine. To this end, the CSC is currently sponsoring several imaging and other cancer biomarker studies.

A particular goal of the CSC is to identify new technologies with the potential to contribute to biologically

\footnotetext{
* Correspondence: dparkinson@nea.com

${ }^{1}$ New Enterprise Associates, Menlo Park, CA 94025, USA

Full list of author information is available at the end of the article
}

informed drug development and clinical medicine. One such area is the emerging field of CTC detection and analysis. The potential implications of successful development of appropriate technologies are very large, and exciting new technologies are under development. However, many questions remain unanswered regarding the biology of CTCs, how best to enumerate and characterize them and the path to regulatory and general clinical acceptance for technology platforms currently under development.

Because of its composition and the skill sets and activities of its member organizations, the Biomarkers Consortium is uniquely positioned to help answer some of these important questions. To this end, the Consortium sponsored a workshop on qualification and validation of CTC assays. This paper summarizes not only the discussions from that meeting, but the outcome of a series of further deliberations by a CTC Working Group (CWG) convened by the CSC. The results will be the basis of a series of clinical studies to be conducted by the CSC to help answer these CTC questions, and move the field forward. 


\section{CTCs: A background}

CTCs have been defined as cancer cells of solid tumor origin found in the peripheral blood. It is generally thought that these cells detach from primary or secondary tumors of patients with advanced cancer prior to detection in the circulation. CTCs are considered very rare, with an estimated frequency of one in 100 million to one in a billion blood cells [1,2]. CTCs have been detected in the peripheral blood of patients with advanced stages of most types of solid tumor cancers, and their presence may represent the hematogenous phase of metastasis since CTCs are often not seen until tumors have achieved neovascularization $[1,3]$. However, CTCs have also been detected in the peripheral blood of patients with localized cancers, which may be indicative of increased risk of progression to metastatic disease [4-10], and very early during tumor development, even at a pre-malignant stage in a pancreatic cancer model [11].

Certain phenotypic characteristics have been utilized consistently to identify CTCs in the peripheral blood. CTCs were initially characterized as non-leukocytic, nucleated cells that are typically epithelial in origin, and maintain significantly larger diameters and total membrane surface areas than normal blood cells. However, the morphological features of CTCs are now known to be less clearly defined, and may vary by disease, disease stage (at the time of diagnosis), or disease state (e.g., pre- vs. posttreatment setting). In addition, a significant number of CTCs may lose their epithelial antigens and express the phenotypic markers of epithelial-mesenchymal transition (EMT), a phenotypic change that is thought to be an important feature in the metastatic process that allows tumor cells to travel to the site of metastasis formation without being affected by conventional treatment [12-15].

It is unknown if CTCs represent more aggressive cells than those in the tumor of origin. However, phenotypic assessments to date suggest that at least some subset of CTCs may represent viable metastatic precursor cells capable of initiating a clonal metastatic lesion [12-15]. In this context, the importance of tumor-stroma interactions in generation and/or maintenance of the cancer "stem"/ tumorigenic cell status (tumor plasticity) should not be underestimated. The resulting molecular and phenotypical alterations are complex and may vary by cancer (sub) type, over time, and by stage of the disease (e.g., [16]). These complexities introduce additional challenges for interpreting CTC analysis results.

The analytical methods/assays used and the degree of their validation will be critical to establishing a common set of criteria describing CTCs. Progress in use of different CTC-related platforms for specific applications in the clinic (beyond CTC enumeration being monitored at multiple time points during the course of patient's treatment) depends on establishing such criteria, keeping in mind how well the malignant features of detectable circulating cells are defined, and in the context of other molecular findings, to what extent identified CTCs could be helpful in detecting emerging resistance to treatment. This latter aspect could be critical for early modification of therapy, thus contributing to personalized health care.

A recent insight derived from CTC analyses has involved finding clusters of CTCs in the circulation of patients with advanced cancer [17-19]. It is not clear whether these aggregates are artifacts of sample processing, or if the detection of clusters has previously been limited by the technologies used for CTC isolation, most of which are purification approaches likely to disrupt clusters [20]. Early studies suggest that CTC clusters may be relatively protected from cell death and the harsh environment and shear stresses of the vascular circulation; they may also be clinically significant; particularly the number, size, or composition of the clusters [17-19,21-23]. The presence of clusters may be a better biomarker for increased metastatic potential than single CTCs $[17,18,22]$.

\section{Major questions to be answered concerning CTCs}

The phenotype(s) of CTCs has not been fully defined. It is currently accepted that CTCs are morphologically EpCAM+, cytokeratin $(\mathrm{CK})_{+}$, and CD45-. However, there is evidence that these cells can also occur in patients with benign diseases of the colon [24] and other phenotypes may be present in the blood of metastatic cancer patients, including CD45+, CK + cells. It has been shown that these double-positive cells can be the result of long storage, and probably represent artifacts (which is consistent with evidence that that $\mathrm{CK}+, \mathrm{CD} 45+$ cells do not have prognostic impact [25]). Further, while CTCs are thought to seed metastatic sites from a primary tumor, there is known discordance between tumor tissue biomarker expression and CTC biomarker expression, as well as heterogeneity of biomarker expression among multiple metastatic sites [26-28]. This suggests that CTCs from metastatic sites can in themselves seed new sites (e.g., [29]). In addition, recent studies have shown that CTC markers may change over the course of therapy (e.g., [30]).

Identification of predictive biomarkers in CTCs has the potential to become a breakthrough in cancer diagnostics and drug development. There are many sensitive and reliable tools that may be used for the characterization of CTCs, including immunocytochemistry, immunofluorescence, laser scanning, fluorescence in situ hybridization (FISH), and polymerase chain reaction (PCR) techniques [9,31-33]. However, statistically meaningful numbers of CTCs may need to be isolated in order to characterize the heterogeneity, determine cellular origin (primary $v s$. metastatic tumor), and evaluate CTC response (signalling, 
proliferation, and apoptosis) after therapeutic interventions. Through initiatives such as the NCI Alliance in Nanotechnology in Cancer, Clinical Tumor Proteomics Analysis Consortium, The Cancer Genome Atlas, and the Physical Sciences in Oncology Centers, the NCI Center for Strategic Scientific Initiatives (CSSI) is contributing to this effort by providing the community with large-scale, reproducible genomic, epigenomic, and proteomic signatures, and with advanced, robust technologies to examine such signatures at high-throughput and high-resolution.

\section{The biomarker development process and development of CTCs as biomarkers}

Validated CTC assays and CTCs qualified as biomarkers of cancer prognosis and response to therapy through the FDA Center for Drug Evaluation (CDER) process have the potential to improve the diagnosis and care of cancer patients, one of the goals of personalized medicine. The FDA defines a validated biomarker assay as an analytical test system with well-established performance characteristics and for which there is an established scientific framework or body of evidence that elucidates the physiologic, toxicological, pharmacologic, or clinical significance of the test results [34]. For qualification, the results of biomarker measurements are expected to have met evidentiary standards within specific contexts of use linking the biomarker result with clinical measurements, and to be reliable for specific interpretations and applications in drug development and clinical and regulatory decision-making.

There are several ways by which biomarkers gain acceptance for regulatory decision making through the FDA. On a case-by-case basis, data on candidate biomarkers that are either used to make decisions in clinical trials or are being considered as a biomarker in human safety studies may be submitted to an investigational new drug application (IND), new drug application (NDA), or biologics license application (BLA) [34]. Alternatively, a test for a biomarker that will be required to support the dose selection, safety, or effectiveness of a drug, and that a sponsor will thus integrate into the drug development program, may be submitted as part of a codevelopment of drug and test combination (i.e., as a companion diagnostic) [35].

Finally, FDA CDER has developed a Biomarker Qualification program as an outgrowth of the Critical Path Initiative to capture consensus on the context of use and supporting data for biomarkers, and to encourage the development of new biomarkers [34]. Through this program, biomarker qualification is defined as "a conclusion that within a carefully and specifically stated 'context of use', the biomarker has been demonstrated to reliably support a specified manner of interpretation and application in drug development". Once qualified, biomarkers can be used in the qualified context in INDs, NDAs, and BLAs; CDER regulatory reviews in all offices and disciplines will adhere to the qualification decision. However, an in vitro diagnostic device, e.g., a CTC test, needed to measure a qualified biomarker is required to be cleared by the FDA Center for Devices and Radiological Health $(\mathrm{CDRH})$ with data supporting the analytical and clinical performance if it is to be used clinically as a diagnostic test, i.e., to inform patient management.

The voluntary process of qualification is intended for biomarkers that will be used as drug development tools [34]. Since public knowledge and access are often essential to the process, collaborative groups such as the Biomarkers Consortium can be useful sources of candidate biomarkers. The process itself provides a framework for interactions between CDER (and often other centers within FDA) and sponsors, with CDER guidance towards the compilation of comprehensive evidence to support the end result of qualification. The interactions include initial evaluation, interactive consultation and advice, and final in-depth review.

An analytically validated assay for the biomarker is a prerequisite for qualification, since the stability, accuracy, and reproducibility of the measurement will be critical to demonstrating utility. Candidate CTC-based biomarkers include the number and/or molecular subclassification of target cells, and among the assays of interest are those that measure these parameters. Criteria for assessing the analytical validity of clinical assays have been published by the Clinical and Laboratory Standards Institute (CLSI), FDA's Office of In Vitro Diagnostics, and other groups [36]. Some considerations for evaluating the analytical and clinical validity of CTC assays are listed below, and reliability of data sources for determining clinical validity are listed in Table 1.

CTC assay analytical validation considerations include the following:

\section{Pre-analytic Variables Controlled}

- Materials at study site, e.g., sample collection tubes, shipping containers

- Materials at analytic laboratory, e.g., assay-specific kit (w/instructions for use, reagents, buffers, controls, etc.), additional equipment (centrifuge, test tubes, micropipettes, vortex mixer, etc.)

- Reagent storage conditions (temperature, time, etc.)

- Specimen collection, e.g., timing of specimen collection relative to study treatments and procedures, phlebotomy procedure (patient positioning, needle size, blood draw site, sample size and number of samples, collection tube, tube inversion for clot prevention)

- Specimen handling e.g., storage time and temperature, shipping time, etc. 


\section{Table 1 Evaluation Criteria for Sources of Clinical Assay Performance Data} Qualitative Rankings of Data Sources and Study Designs

\begin{tabular}{ll}
\hline Most Reliable & $\begin{array}{l}\text { Collaborative studies that use large panels of } \\
\text { well characterized samples; summary data from } \\
\text { well-designed external proficiency testing schemes } \\
\text { inter-laboratory comparison programs }\end{array}$ \\
Reliable & $\begin{array}{l}\text { Other data from proficiency testing schemes, } \\
\text { well-designed peer-reviewed studies, and } \\
\text { expert panel-reviewed FDA summaries }\end{array}$ \\
Less Reliable & $\begin{array}{l}\text { Less well designed peer-reviewed studies } \\
\text { Least Reliable }\end{array}$ \\
& $\begin{array}{l}\text { Unpublished and/or non-peer reviewed } \\
\text { research; clinical laboratory, or manufacturer } \\
\text { data; studies on performance of } \\
\text { the same basic methodology, but used to test } \\
\text { for a different target }\end{array}$
\end{tabular}

Criteria for Assessing the Internal Validity of the Studies Used to Obtain Data

- Adequate descriptions of the assay platform and test procedures, including the reproducibility of test results, quality control measures, and comparison to a "gold standard" reference assay.

- Samples representative of the study population, blinded testing and interpretation

- Data analysis including point estimates of sensitivity and specificity with 95\% confidence intervals, and sample size/power calculations.

- Studies graded as convincing, adequate, or inadequate based on their ability to provide confident estimates of analytic sensitivity and specificity using intended sample types from representative populations.

Analytic Variables Controlled

- Type of analysis (enrichment/enumeration/ molecular characterization of target cells)

- What is the range of specimens tested?

- Sensitivity of assay (enrichment/enumeration/ molecular characterization of all cells)

- Specificity of assay (enrichment/enumeration/ molecular characterization of only target cells)

- How often does the assay give a useable result?

- How similar are the results with repeated measurements?

- What are the analytical range, reproducibility, and clinical applicability of the test?

- How similar are the results obtained within the same or in multiple laboratories using the same or different technology?

- Assay-specific controls should be run each day of analysis or when a new assay lot is used to check overall performance, including instrument, reagents, and operator technique

- Assay-specific controls should be run regularly (monthly or quarterly) to show performance at the lower limit of analysis

- Assay-specific samples should be run semi-annually to document the lower limit of quantitation
- Calibration/calibration verification (at least semiannually)

Post-analytic Variables

- All participating laboratories in the same study should use common controls to document continuously across laboratory performance.

- Splitting samples across laboratories prior to the study is recommended to document assay performance across laboratories.

CTC assay clinical validity considerations include the following:

\section{Assay Characteristics}

- Clinical sensitivity and specificity of assay

- Are there methods to resolve clinical false positive assay results in a timely manner?

\section{Disease Characteristics}

- Prevalence (how often are the target cells detectable in the study population?)

- What is the relationship between detectable target cells and the study disease?

- Positive predictive value (what is the probability that a positive assay result means that the subject has the target disease?)

- What are the genetic, environmental, or other modifiers for detection of the target cells?

A working group formed at the NCI-European Organisation for Research and Treatment of Cancer (EORTC) First International Meeting on Cancer Diagnostics convened in Nyborg, Denmark, in July 2000 created a set of criteria for high quality reporting of biomarker studies [37]. The guidelines evaluate study design, methods, and analyses; and provide suggestions for the types of data elements that should be reported. These guidelines will be useful in obtaining data for evaluating and comparing CTC assays.

During clinical validation prospective clinical studies may be designed to show evidence of the link between the biomarker being measured and the specific biologic process or clinical outcome. Sometimes, links between a candidate biomarker and a biologic process or clinical outcome can be supported by examining retrospectively collected data or specimens for which the process or outcome in question is known, but this will generally provide only exploratory information that will need prospective confirmation. Retrospective collections of samples are not expected to contain stable/viable/molecularly unaltered CTCs, due to the labile nature of live cells once removed from the body. 


\section{Potential contexts of use for CTCs}

Many potential clinical contexts of use exist for CTCs. Detection of CTCs may potentially be used to establish a diagnosis, as an alternative to invasive biopsies for early detection of metastatic tumor tissue, and for monitoring cancer patients [21,38-40]. CTCs also have potential for investigation of heterogeneity in biomarker expression between primary tumors and distant metastases, as well as among multiple metastatic sites [9,26-28,30,41]. Particularly interesting to the Biomarkers Consortium, the numbers and characteristics of CTCs may be prognostic for survival or predictive of response to cancer therapy in general or of response to a specific therapy. Moreover, changes in CTCs during the course of therapy may serve as biomarkers of treatment response or resistance.

Assays that enumerate or report the number of CTCs in a whole blood sample of a patient with advanced cancer have been shown to be prognostic for survival [4244]. CTC enumeration via the Veridex CellSearch ${ }^{\mathrm{TM}}$ System is FDA-cleared for use as an aid in monitoring patients with metastatic breast, colorectal, and prostate cancers (FDA, CDRH). The presence prior to treatment of $\geq 5$ CTCs in a $7.5 \mathrm{ml}$ sample for metastatic breast and prostate cancers, and $\geq 3$ CTCs for colorectal cancer is associated with decreased progression-free and overall survival, and is prognostic, regardless of therapy used. Recent studies have also shown the potential utility of the CellSearch ${ }^{\mathrm{TM}}$ assay for monitoring patients with melanoma, urothelial, and lung cancer [45-48].

Beyond enumeration, molecular profiling of CTCs has the potential to provide predictive information to guide the selection of therapy [49,50]. For example, although several studies have not seen this correlation $[9,41,50]$, other studies indicate that there is concordance for human epidermal growth factor receptor 2 (HER2) gene status between primary breast cancer tumors and CTCs. This suggests that targeting patients with HER2-positive $($ HER2+) CTC test results with the anti-HER2 antibody trastuzumab may significantly improve clinical outcomes for HER2+ breast cancer (e.g., [51]). CTC characterization may also aid in accelerating drug development and approval, since the focus of many current oncology drug discovery efforts is developing targeted therapies against signalling proteins implicated as important drivers of aggressive tumor growth and survival. A key step in the successful clinical development of such agents is the identification of responsive or resistant patient populations with predictive biomarkers for these therapies. The study of detailed molecular signatures for individual CTCs may also provide leads in new drug discovery by assessing the markers unique to progression so that relapsing patients can be treated for their current "molecular disease".

As cancer cells can be more frequently sampled in circulation than through tumor biopsy, characterization of
CTCs over time can provide an opportunity to better assess dynamic physiologic responses to treatment. Measuring CTCs sequentially during the course of therapy may reveal tumor evolution under therapeutic "natural selection" and permit the identification of biologic determinants of drug resistance or progression (e.g., secondary mutations) $[9,52,53]$. In this regard, evolutionary biologists working with the NCI Office of Physical SciencesOncology, are discovering instantaneous and long-term responses in more than 150 patients by examining robust data generated by high-content CTC platforms using $\sim 2500$ samples collected at regular timed intervals.

Post-therapy changes in CTCs might be an easily accessible intermediate point-of-response efficacy. Further, a number of cases have shown that CTC numbers change prior to changes being seen with anatomical imaging, and that CTC analysis may be a more robust surrogate of survival than anatomical imaging; so CTCs potentially may have more utility in the clinical setting $[9,10,54]$. CTC evaluation might ultimately be used as a surrogate measurement of clinical benefit and therefore an endpoint in clinical research.

A major challenge in processing and analyzing CTCs is their low concentration in blood. For example, detailed standard protocols for controlling pre-analytic variables associated with collection and handling of blood samples are likely needed to ensure reproducibility of assay results (see below under Standards). A wide range of assay platforms is currently under development for analysis of CTCs [29,32,50,55]; the developers seek to optimize both sensitivity and specificity for detecting CTCs and to avoid generation of artifacts from extensive processing. Whole blood sample enrichment for CTCs generally involves density gradient centrifugation, immunomagnetic isolation, microfluidics, or some combination of techniques. CTC enumeration platforms are generally image-based approaches using immunocytochemistry or laser scanning cytometry, and CTC characterization techniques are typically nucleic acid or protein-based molecular assays, imaging, or a combination of molecular and imaging methods. As suggested by the background discussion above, each assay platform will likely have strengths and weaknesses in evaluating various aspects of CTCs. For instance, assays using immunomagnetics with anti-EpCAM antibodies are very efficient at enriching for epithelial cells but may miss cancer cells that have undergone EMT.

A number of promising techniques reported in the past few years use microfluidic devices to isolate CTCs from whole blood. In addition to enabling detection of CTCs in small blood samples, key design features of these techniques are flow patterns to optimize exposure of blood cells to the CTC detection method (often anti-EpCAM antibodies) and to minimize nonspecific leukocyte 
binding, as well as provision of platforms for molecular characterization of the captured cells. For example, among the microfluidics-based devices is one in which blood is pumped across a silicon-etched chip containing thousands of microposts fitted with anti-EpCAM antibodies. EpCAM-positive cells attach to the microposts and are then analyzed using dyes and imaging [7]. An enhanced version of this CTC Chip uses microvortices in a herringbone pattern to increase the number of interactions between CTCs and the antibody-coated chip surface [17]; DNA from cells captured on the chip are extracted and analyzed for specific molecular targets [52]. Another microfluidics device contains sinusoidal micro channels coated with anti-EpCAM antibodies to capture CTCs; the captured cells are detached from the micro channels using trypsin and passed through a conductivity sensor on the device for enumeration [56]. Specific to prostate cancer, a microfluidic device with a three-dimensional flow pattern has been described that uses anti-prostate specific membrane antigen (PSMA) antibody to capture CTCs (PSMA+, CD45- cells) [57]. Captured cells are fixed on the device and stained for PSMA, EpCAM, and presence of a nucleus; CTCs are enumerated with the aid of confocal microscopy. The captured cells can be made permeable to enable detection of intracellular antigens (e.g., TMPRSS-ERG fusion protein) or lyzed for RNA extraction. Table 2 lists some of the more widely publicized CTC assays and assay platforms being developed for commercial use, including those with microfluidic and microarray technology.

\section{Selection of CTC technologies for clinical development}

One of the goals of the Biomarkers Consortium Workshop was to bring together experts in the field of CTC research to identify and implement practical ways of comparing the performance of the most promising CTC assay technologies at equivalent levels of development as an initial step in clinical validation. This work, viewed as a preliminary step, was necessary to determine the value of a particular technology for inclusion in clinical trials. Discussions from the workshop and recommendations from subsequent CWG meetings are summarized below.

\section{Practical application}

Selected CTC assays could range from relatively low technology immunoassays for enumeration to more advanced technology platforms for molecular analysis, but priority should be given to examination of technologies with robust analytical validation and potential for providing data to address the key questions regarding biology and clinical significance of CTCs.

Clearly, different technologies may be more or less appropriate for specific applications, and more than one assay may be required for different contexts of use in a given patient. For example, a technology optimized for enumeration might not be optimal for providing enriched or purified CTC populations for detailed biological characterization. Therefore, no simple generalization can be made about the "ideal CTC technology". Nevertheless, general comments can be made regarding characteristics which each technology should possess.

For example, the CTC technologies selected for evaluation should be ready to use in a clinical laboratory setting (see Table 3). Standard reference materials for the assay should be available and readily accessible by laboratories involved in clinical studies, and standards should be in the clinically informative range (able to show that quantitation or other analysis is accurate and reproducible at the cut-off level). As noted above, the assays selected should already have published performance data with a known performance at the level that is appropriate for use in clinical trials; depending on the technology, there should also be independent analytical validation for different organ systems. The effects of pre-analytical variables related to biospecimen acquisition, processing, and transportation should be predetermined for each assay type and serve as the evidence base for standardized procedures to obtain and handle assay samples. Each assay should demonstrate a relevant dynamic range in response; where appropriate, the assay should provide capabilities for identifying biologically relevant point mutations and ideally capture viable cells for additional analyses. Each testing laboratory needs to validate the assay using the manufacturer's published data as guidance in developing internal validation criteria.

\section{Standards}

Workshop participants and the CWG strongly endorsed the development of standard language for describing CTCs and of standard operating procedures (SOPs) for clinical evaluation of CTC assays prior to any testing on patient specimens. For example, different CTC subtypes may need to be defined, and the definitions should be context-dependent. Creating a panel of criteria for describing CTCs that together can provide statistical confidence provides an alternative approach.

Pre-analytic protocol standards for acquiring, handling, and transporting samples, and acquiring, processing, and interpreting assays are needed to allow collaboration among centers at a level of detail sufficient to encompass all likely variables. These standards should enable comparisons across platforms, contexts of use, and time. Efforts should be made to develop protocols for evaluating technologies that are uniform and clinically meaningful with regard to well-defined parameters for specific applications. Though ideally flexible enough so that new technologies can be easily integrated, the standards should be evaluated rigorously. 
Table 2 CTC Assays and Technologies

\begin{tabular}{|c|c|c|c|c|}
\hline Assay/Technology Name & Manufacturer/Developer & Assay Outcome & Target Cancer(s) & Technology/Process \\
\hline AdnaTest & AdnaGen, Langenhagen, Germany & Enrichment/Characterization & Breast, Prostate, Colon & $\begin{array}{l}\text { Immunomagnetic-based EpCAM enrichment } \\
\text { using labelled beads incubated with the } \\
\text { whole blood sample. Unlabeled cells are } \\
\text { removed; labelled cells are then lyzed. RNA is } \\
\text { isolated, followed by multiplex RT-PCR } \\
\text { (GA733-2, HER2, MUC1) to detect specific } \\
\text { tumor biomarkers. }\end{array}$ \\
\hline $\begin{array}{l}\text { Anti-EpCAM/Anti-CK } \\
\text { Antibody CTC Enrichment }\end{array}$ & $\begin{array}{l}\text { Glenn Deng, Stanford } \\
\text { University, Stanford, CA }\end{array}$ & Enrichment/Enumeration & Metastatic Breast Cancer & $\begin{array}{l}\text { CTC enrichment assay using the combination } \\
\text { of anti-CK and anti-EpCAM antibodies. Image } \\
\text { analysis performed using the Ariol }{ }^{\circledR} \text { system. } \\
\text { CTC identification with brightfield and } \\
\text { fluorescence labelled anti-CK, } \\
\text { anti-CD45, and 4',6-diamidino-2-phenylindole } \\
\text { (DAPI) images. }\end{array}$ \\
\hline ApoStream $^{\mathrm{TM}}$ & ApoCell & Enrichment & Prostate, Lung & $\begin{array}{l}\text { Isolation of CTCs in a whole blood sample } \\
\text { using dielectrophoretic field flow fractionation } \\
\text { (DFFF), which separates cells based on } \\
\text { differing dielectric properties. See also DFFF } \\
\text { technology entry below. }\end{array}$ \\
\hline $\begin{array}{l}\text { autoMACS/MACS (Magnetic } \\
\text { Activated Cell Sorting System) }\end{array}$ & $\begin{array}{l}\text { Mitenyi Biotec, Bergisch } \\
\text { Gladbach, Germany }\end{array}$ & Enrichment & -二-—-二- & $\begin{array}{l}\text { Utilizes an immunomagnetic column to } \\
\text { capture cells with various antigens (EpCAM, } \\
\text { pan-CK, HER2/neu, or CD45). Manual or } \\
\text { semi-automated system. These viable cells are } \\
\text { available for subsequent analysis following } \\
\text { enrichment. }\end{array}$ \\
\hline Bioflux & $\begin{array}{l}\text { Fluxion Biosciences, South } \\
\text { San Francisco, CA }\end{array}$ & Enumeration & -—— & $\begin{array}{l}\text { Well Plate Microfluidic }{ }^{\top M} \text { technology to obtain } \\
\text { physiologically-relevant data from cell-based } \\
\text { assays. Data acquisition obtained in brightfield, } \\
\text { phase, fluorescence, and confocal } \\
\text { high-resolution microscopy. }\end{array}$ \\
\hline \multirow{2}{*}{$\begin{array}{l}\text { CEER (Collaborative Enzyme } \\
\text { Enhanced Reactive) Immunoassay }\end{array}$} & Prometheus Laboratories Inc. & \multirow[t]{2}{*}{ Characterization } & -——- & \multirow{2}{*}{$\begin{array}{l}\text { Multiplexed protein microarray platform that } \\
\text { measures the expression and activation of } \\
\text { specific cancer pathways with high levels } \\
\text { of sensitivity and specificity. }\end{array}$} \\
\hline & $\begin{array}{l}\text { Bayer Schering Pharma AG, } \\
\text { Germany }\end{array}$ & & & \\
\hline CELLection $^{\mathrm{TM}}$ Epithelial Enrich & $\begin{array}{l}\text { Traci Libby, Invitrogen, } \\
\text { Carlsbad, California }\end{array}$ & Enrichment & -二-二-二- & $\begin{array}{l}\text { Positive isolation. Obtain up to } 5 \text { log } \\
\text { enrichment of viable epithelial tumor cells } \\
\text { that are suitable for immunocytochemical } \\
\text { staining or any other downstream } \\
\text { application. }\end{array}$ \\
\hline CellSearch $^{T m}$ & Veridex & Enrichment/Enumeration & $\begin{array}{l}\text { Metastatic Breast, Colon, } \\
\text { Prostate, Lung, Melanoma, } \\
\text { Urothelial Cancer }\end{array}$ & $\begin{array}{l}\text { Automated immunomagnetic enrichment } \\
\text { and staining system for quantification of } \\
\text { CTCs in whole blood samples. CTCs } \\
\text { are enriched using ferrofluids coupled to } \\
\text { anti-EpCAM antibodies and identified by } \\
\text { cytokeratin staining using fluorescent } \\
\text { anti-CK antibodies, as well as counterstaining }\end{array}$ \\
\hline
\end{tabular}


ClearCell System (CTChip and Clearcell Unit)

\section{CTC Chip}

CTC Membrane Microfilter

Cytoscale CTC Assay

DEPArray

\section{Dielectrophoretic Field}

Flow Fractionation(DFFF)

Dylight Technology
Developers:

\section{On-Q-ity, Waltham, MA}

ICx Biosystems, San Diego, CA

Johnson \& Johnson

Richard Cote, Ram Datar,

University of Miami, FL

Hsian-Rong Tseng, University

of California, Los Angeles

Nicolo Manares, Silicon Biosystems, SpA, Bologna, Italy

Peter Gascoyne, MD Anderson

Cancer Center, Houston, TX

Medical University Graz, Austria with anti-CD45 antibodies. Currently, the only diagnostic test cleared by the FDA.

Detects and isolates intact, viable CTCS

from small quantities of whole, unprocessed

blood. Isolated CTCs can then be stained

directly on the CTChip ${ }^{\circledR}$ for identification,

or retrieved for further molecular analysis.

Enrichment using microfluidic technologywhole blood is pumped across a

silicon-etched chip that contains 78,000

microposts fitted with anti-EPCAM antibodies.

EpCAM-positive cells attach to the microposts and are then detected by a camera. Includes a chamber to enclose the fluid and chip and a pneumatic pump.

Stepwise photolithography process that produces controlled-size pores designed to exploit cell size differences between tumor and normal blood cells. Combined with quantum dot-based immunofluorescence detection for CTC characterization.

Antibody cell-surface marker capture enhanced by nanostructures:

immunohistochemistry staining for cell identification.

Cell microarray for individual cell

manipulation and detection. The base is a microelectronic active silicon substrate embedding control circuitry for addressing each individual dielectrophoretic (DEP) cage (cage size can be set to accommodate a single cell). The system allows detection and sorting of rare cells and sorting by morphological parameters such as shape, nucleus-to-cytoplasm ratio, fluorophores co-localization (by image-based selection)

Cell-separation technique that exploits the differences in density and dielectric properties of cells to aid isolation of CTCs from clinical blood specimens. See also ApoStream ${ }^{\text {TM }}$ assay above.

Enumeration

method for identifying

CTCS that utilizes staining for multiple markers, including CD44, ALDH1, and CK using DyLight dyes; and subsequent analysis by novel DyLight technology. 
Table 2 CTC Assays and Technologies (Continued)

Dynabeads $^{\circledR}$ CD45 Traci Libby, Invitrogen,

Carlsbad, California

\section{Dynabeads ${ }^{\circledR}$ Epithelial Enriched}

Traci Libby, Invitrogen

Carlsbad, California

Epic HD-CTC Assay

EPISPOT (EPithelial ImmunoSPOT)

Catherine Alix-Panabieres and Klaus Pantel, Laboratoire de Virologie, Hôpital Lapeyronie, CHU Montpellier France \& UKE, Hamburg, Germany

\section{FAST Cytometer(Fiberoptic Array Scanning Technology)}

\section{Flow Cytometry}

HB-CTC (Herringbone-Chip)

ISET (Isolation by Size of Epithelial Tumor cells)

IsoFlux ${ }^{\mathrm{TM}}$ Rare Cell Access System

Laser Scanning Cytometry
Fluxion Biosciences, South San Francisco, CA

Peter Kuhn, Scripps Institute, La Jolla, CA

Robert Bruce, Scripps Palo Alto Research Center, Palo Alto, CA

Jeannie Gaylor, Becton-Dickinson, San Jose CA

Mehmet Toner and Daniel Haber, Massachusetts General Hospital (MGH) and Harvard Medical School

\section{Metagenex, Paris, France}

Enrichment

Enrichment

Maintrac, Bayreuth Germany
Enrichment

Enrichment

Enumeration/Characterization

Prostate, Breast, Pancreas

Breast, Prostate, Colon

Characterization

Enrichment/Enumeration

Enrichment/Enumeration

Enumeration/Characterization
Breast, Colon, Prostate, Sarcoma
Dynabeads ${ }^{\circledR}$ are coated with anti-CD45

monoclonal

of human leucocytes in whole blood samples

to enrich epithelial tumor cells.

Dynabeads ${ }^{\circledR}$ are coated with the monoclonal antibody BerEP4 against the human epithelial antigen, EpCAM. Enriched tumor cells are lysed for mRNA isolation and RT-PCR amplification.

CTC detected in peripheral blood through red blood cells lysis and fluorescently labeled antibodies. See also FAST Cytometer entry.

After depletion of CD45 positive cells, remaining cells in a whole blood sample are cultured for 24 hours on a membrane coated with antibodies that detect proteins shed from viable CTCs by secondary antibodies labelled with fluorochromes.

Fluorescence cytometry combined with an automated digital microscopy imaging system. Immunofluorescently labelled CTCS are detected on a glass slide using laser-printing optics, which can scan 300,000 cells per second. See also Epic HD-CTC Assay entry.

Multiple reagents and systems adaptable to analysis or sorting of CTCs.

A high-throughput microfluidic mixing device which provides an enhanced platform (over the CTC-chip) for CTC isolation where microvortices are utilized to significantly increase the number of interactions between target CTCs and the antibody-coated chip surface.

CTCs are separated from other cells in whole blood by size via vacuum filtration. This technique is gentle and produces viable cells that can be further analyzed following enrichment.

Proprietary microfluidic technology to isolate rare cells with high efficiency. The system incorporates CellSpot ${ }^{\text {TM }}$ Technology to produce a highly concentrated sample that is optimized for downstream molecular analyses.

Custom laboratory analysis service performed on slides using a variety of fluorochrome- 


\section{Multiphoton Intravital}

Flow Cytometry

Nanodetector

Negative Enrichment OMS

Nucleopore Assay

OncoCEE-BR ${ }^{\mathrm{TM}}$
ApoCell

Axis-Shield PoC, Oslo, Norway

Stephanie Jeffrey and Ronald W. Davis, Stanford University, Stanford, CA

Philip Low, Purdue University, West Lafayette, IN

Enumeration

Prostate

Gilupi, Potsdam, Germany

Jeffrey Chalmers, Cleveland Clinic, Cleveland, $\mathrm{OH}$

PerCelleon, LLC

Stem Cell Technologies

Whatman International Ltd., UK

Biocept, Inc. and Clarient, Inc labelled antibodies or other techniques

e.g., estrogen receptor, HER2

prostate-specific antigen, FISH, terminal dUTP

nick end labelling). Traceable single cell

detection within 1 million cells.

Proprietary microscope-based

mmunofluorescent image analysis.

Separates mononuclear cells from other cells in whole blood based on cell density.

Automated immunomagnetic

enrichment-gently enriches target cells

and eliminates cells that are not bound to

magnetic particles. Isolated cells can be

extracted individually based on their physical

characteristics to deplete any cells

nonspecifically bound to beads. Processes $9 \mathrm{~mL}$

of blood per hour and captures $>50 \%$ of

circulating epithelial cells as measured in

spiking experiments.

Noninvasively counts rare CTCs in vivo as they flow through the peripheral vasculature.

The method involves intravenous injection of a tumor-specific fluorescent ligand followed by multiphoton fluorescence imaging of superficial blood vessels to quantitate the flowing CTCS.

The nanodetector (functionalized structured medical wire, FSMW) is inserted into the patient's arm vein via a standard 20-gauge needle. The nanodetector consists of a medical stainless steel wire, coated with a gold layer and a hydrogel functionalized with an anti-EpCAM antibody. During the $30 \mathrm{~min}$ application in the vein, up to $1,500 \mathrm{~mL}$ of blood including the respective CTC pass the nanodetector and enable a high number of CTC to be bound by the anti-EpCAM antibody. Red cell lysis, immunomagnetic labelling and subsequent depletion of CD45+ cells (leukocytes). Remaining cells may be further characterized (epithelial cells, cells undergoing EMT).

CTCs are separated from other cells in whole blood by size via vacuum filtration.

OncoCEE ${ }^{\text {TM }}$ captures CTCs via a microfluidic system that uses multiple antibodies for 
OncoQuick

Optofluidic Intracavity Spectroscopy (OFIS)

Photoacoustic Detection

\section{RARE (RosetteSep-Applied}

Imaging Rare Event)

RoboSep/EasySep ${ }^{\mathrm{Tm}}$

ScreenCell ${ }^{\circledR}$ Cyto, ScreenCell

CC, ScreenCell ${ }^{\circledR}$ MB
Greiner Bio-One, Germany,

North Carolina

David Kisker eOptra, Longmont, CO

Enumeration

John Viator, University of Missouri, Columbia, MO

StemCell Technologies, Vancouver, BC

Enrichment

Stem Cell Technologies, Vancouver

Enrichment

ScreenCell Company Biopark 12 rue

J-A de Baif 75013, Paris capture followed by detection using

CEE-Enhanced staining and then detects their HER2/neu status via FISH.

Centrifugal separation using optimized liquid media based on tumor cell buoyant density only. Achieves enrichment of up to 6 logs from approximately $10^{4}$ total mononuclear cells. Validated with spiking studies.

OFIS has been used to investigate the properties of several tumor cell lines and compared the results to cells from periphera blood. The results suggest that a unique optical signature may be a characteristic of many tumor cells. This signature may offer a complementary tool to molecular methods for detection and enumeration of CTCs. In addition, by using dielectrophoresis to trap and steer cells, it is possible that induced changes in the OFIS spectrum may detect other characteristics of tumor cells, as well as transport and sort them according to those characteristic properties.

Melanoma, Breast Cancer Flowmetry system in which blood samples are irradiated with laser light, and are irradiated with laser light, and
photoacoustic waves from cancer cells are photoacoustic waves from cancer cells are
detected and counted (uses melanin in melanoma, gold-tagging of other cancer cells).

Negative selection technique where tetrameric antibody complexes crosslink CD45-expressing leukocytes to red blood cells in whole blood. These complexes pellet to the bottom of the tube when centrifuged due to increased density, enriching CD45-negative cells (CTCS).

Myeloma, Epithelial Tumors,

Immunomagnetic nanoparticle-cell complexes are captured in tubes and unlabeled cells are poured off. Adaptable to custom CTC antibody surface antigens. Manual or semi-automated systems.

The ScreenCell ${ }^{\circledR}$ Cyto device isolates rare tumor cells, with a high recovery rate. The ScreenCell ${ }^{\mathbb{B}}$ CC device allows isolation of either fixed or live cells. Fixed cells are well preserved morphologically.

Immunocytochemistry and FISH assays can be performed directly on the filter. Isolated live cells are able to grow in culture. High-quality genetic materials (DNA, RNA) can be obtained 
Single Cell Gene Expression with BioMark $^{\mathrm{Tm}}$ Real-Time PCR System

Fluidigm Corporation, South San Francisco, CA
Characterization

Enumeration/Characterization

Breast, Others? San Jose CA

Enumeration/Characterization

Gastric, Breast
Oncolys BioPharma, Tokyo directly from tumor cells isolated on the

ScreenCell ${ }^{\circledR} \mathrm{MB}$ device filter. The ScreenCell ${ }^{\circledR}$

devices may be able to simplify and improve

noninvasive access to tumor cells due to their

reduced size, versatility, and capacity to isolate

CTCS within minutes.

Allows high-throughput cell-line studies to

determine individual cell behavior and is

suited to determine single-gene cell expressio

levels in CTCs. Results are presented as a heat

map, with individual assays on the $X$-axis and

individual cell samples on Y-axis. The

intersection of each assay and sample is an

individual real-time GPCR reaction.

Commercial component to automatically track review, and enumerate immunocytochemically stained candidate CTCS. Nuclear, shape factor morphology image analysis system with

computer display.

Uses a virus vector for CTC detection. The virus is incubated with whole blood sample for $24 \mathrm{hrs}$ and replicates with cancer cells, incorporating and GFP marker into them. CTCs are detectable by fluorescence system analysis of detectable by fluorescence system analysis of
cell preparation on slide. Potential for in vivo transfection and detection of GFP + CTCs in capillary bed of patient.

CAM ingestion. Enables molecular characterization of captured cells.
Vita-Assay[Functional Collagen

Adhesion Matrix (CAM)]

Wen-Tien Chen, Vitatex, Stony Brook, NY

Enumeration

Prostate

(Commercial and Being Developed for Commercial Application). 
Table 3 CTC Assay Clinical Readiness Evaluation

\begin{tabular}{|c|c|}
\hline \multicolumn{2}{|r|}{ Assay Validation } \\
\hline \multirow[t]{4}{*}{ Pre-Analytic } & $\begin{array}{l}\text { How is specimen collected (venous route, body } \\
\text { position, draw order, tourniquet time, needle bore, } \\
\text { tube type)? }\end{array}$ \\
\hline & $\begin{array}{l}\text { When is specimen collected (time of day, relative to } \\
\text { treatment, relative to infusates)? }\end{array}$ \\
\hline & How is specimen stored (time and temperature)? \\
\hline & How is specimen handled (shipping, transfers)? \\
\hline \multirow[t]{5}{*}{ Analytic } & Sensitivity (lower limit of quantitation)? \\
\hline & Reportable range? \\
\hline & Specificity? \\
\hline & Reproducibility? \\
\hline & Robustness? \\
\hline \multirow[t]{3}{*}{ Post-Analytic } & How is data reported? \\
\hline & How is data analyzed? \\
\hline & What are the reference intervals? \\
\hline \multicolumn{2}{|c|}{ Clinical Feasibility } \\
\hline \multicolumn{2}{|c|}{$\begin{array}{l}\text { - Are there analytically valid results when tested in appropriate } \\
\text { preclinical models? }\end{array}$} \\
\hline \multicolumn{2}{|c|}{ O with use of clinically relevant/feasible specimen acquisition? } \\
\hline \multicolumn{2}{|c|}{$\begin{array}{l}\text { O with use of clinically relevant specimen handling procedures } \\
\text { (both at the point of acquisition and in the receiving laboratory)? } \\
\text { These processes should be tracked and recorded. }\end{array}$} \\
\hline \multicolumn{2}{|c|}{ O with use of clinically relevant collection scheduling? } \\
\hline \multicolumn{2}{|c|}{ Therapeutic Relevance } \\
\hline \multicolumn{2}{|c|}{$\begin{array}{l}\text { - For predictive biomarkers, is there a relationship between dose/ } \\
\text { exposure, quantifiable target modulation, and disease outcome? }\end{array}$} \\
\hline \multicolumn{2}{|c|}{$\begin{array}{l}\text { - For prognostic biomarkers, is there a relationship between baseline } \\
\text { levels and survival? }\end{array}$} \\
\hline
\end{tabular}

While specific procedures for sample acquisition, handling, and processing should probably be dictated by the analysis to be done, general recommendations for sample handling should be made. Pre-analytical variables, including fasting status, time of day, body positioning during the blood draw, and venipuncture needle size should be standardized. It also may be desirable for CTC assay platform companies to supply completely self-contained collection kits to minimize the pre-analytic variability. Procedures for handling acquired samples, including sample transport and storage, should also be standardized and deviations tracked variables related to sample collection and analysis are listed following:

\section{Materials at Site}

- Sample collection kit with instructions for use

- Shipping container

- Temperature monitoring strips

\section{Materials at Lab}

- Appropriate analytical instrumentation
- Analytical reagents

- Standards

- Multiple levels of controls

Precollection Variables

- Reagent storage temperature

- Reagent storage time

- Patient preparation-for example, fasting status

Sample Collection Variables

- Timing of sample collection in study protocol

- Sample collection method

- Number of specimen collected, including duplicates

- Subject positioning during sample collection

- Specimen transport time

- Specimen storage temperature

- Specimen storage time

- Assay-specific SOPs

- Lot-specific control testing

- Levels of quality control testing (daily, monthly)

- Lab certification

- Assay platform training

All testing should use rigorous criteria such as Clinical Laboratory Improvement Amendments (CLIA) or good laboratory practice (GLP) standards. Early-stage development studies of clinical assays are not subject to CLIA regulation; however, clinical trials where biomarker assays are integral to the design need to be done in CLIA-certified laboratories, and if the results of the assay are used to make treatment decisions, FDA review is generally needed. Biomarker assays are considered to play an integral role when done in real time and the results used for trial eligibility or to make individual patient decisions-for example, to stratify patients, assign a patient to a specific treatment arm, or decide whether to escalate dose or stop treatment [58].

The fragility/lability of tumor cells introduces an important source of variability in the evaluation of CTC assay platforms that analyze captured whole cells, since CTC apoptosis begins very early after separation from the tumor of origin and after removal of blood from the patient [59-61]. Incorporating cellular preservatives in the collection of peripheral blood samples has been shown to stabilize CTCs for up to 96 hours [25,32,61]. Standard use of this procedure would allow greater flexibility in sample storage and shipping, which in turn may allow the inclusion of more enumeration assay technologies in comparison evaluations, and make their utilization in the clinic more practical.

Archived CTC samples may be adequate for molecular-based assays, assuming that one is able to demonstrate that the cells of interest have survived the archiving procedure and duration in numbers and 
biological condition that represent their state when collected. However, access to systematically collected and appropriately well-preserved patient samples with linked clinical outcome data is essential [62]. For CTC studies in general, archived tumor samples may be difficult to obtain, suboptimal for certain molecular assays, or not representative of a patient's disease at the time of treatment. The NCI has provided detailed recommendations related to biospecimen and data quality in the 2010 Revised NCI Best Practices. The NCI Office of Biorepositories and Biospecimen Research (OBBR) is one resource for well-defined archived samples that are collected using the most stringent SOPs.

Established in 2005, a goal of OBBR is to develop a common biorepository infrastructure to facilitate multiinstitutional genomic and proteomic studies. Partnering with an organization like OBBR to develop CTC-specific SOPs, as well as a source of clinical samples for assay comparison studies, should be considered.

\section{Initial interassay comparison on clinical samples}

For most new CTC technologies reviewed, it was noted that too little systematically collected data were available to allow evaluation of potential clinical utility or to compare with other assays. Beyond analytical validity, foundational data on the individual assays are needed, such as frequency of detection in specific patient populations and consistency of the results in a given patient in determinations on multiple days and at different time intervals, as well as the capability for detecting quantifiable changes to a patient's results after appropriate treatment.

Specificity of a CTC assay depends on a particular test result representing the target tumor cells, as opposed to normal hematopoietic or circulating epithelial cells. This distinction can often be made by either visual inspection by a trained cytopathologist or by determination of molecular markers, or a combination of these techniques. For example, Meng et al. have demonstrated that in patients with metastatic breast cancer, epithelial cells identified using an immunomagnetic separation system with anti-EpCAM as the capture antibody are highly aneusomic and almost certainly malignant and not normal [60]. Further, Shaffer et al. demonstrated that cells captured by CellSearch $^{\mathrm{Tm}}$ expressed prostate specific antigens and had molecular features of malignancy as determined by FISH analysis [38].

However, it is conceivable that not all cells that meet visual or molecular criteria for cancer have true malignant potential or, conversely, that not all cells lacking the defined criteria are nonmalignant (e.g., [24,63]). Current thought is in part based on stem cell theory, which posits that only a fraction of any tumor mass, and therefore of any CTC population, is able to establish and maintain a metastasis. Also as suggested above, it is known that many cells identified in the circulation are already undergoing, or have completed, apoptosis. Therefore, biologic relevance is not just the presence of unequivocally malignant-appearing cells, but the biological and/or clinical significance of these cells. The latter can only be determined by correlating the presence of assay metrics (presumed CTCs) with some clinically or biologically important outcome, such as tumor regression, subsequent recurrence, new primary cancer, or death.

The implication of biologic significance is that one cannot conclude that a new assay is superior to a goldstandard assay by mere comparison of assay metrics/unit blood between the two. One must determine whether a presumably more sensitive assay retains, or exceeds, the robust separation of outcomes between patients who are positive $v s$. those who are negative for the assay, and this can only be demonstrated in well-designed clinical studies.

Direct comparison of different technologies on the same clinical samples and/or in tumor cell spiking experiments would be informative. One or two specific CTC-derived biomarkers (e.g., EpCAM) could be used to identify the optimal assay technologies. Gold-standard technologies are needed for comparisons, based on whether the evaluation is quantitative (enumeration of CTCs) or qualitative (molecular characterization of CTCs). CellSearch ${ }^{\text {TM }}$ could serve as an anchor in the short term for assessments of newer enumeration assay technologies, building on prior clinical evidence for its predictive and prognostic capability.

The CWG discussed approaches to carry out this evaluation in which the Biomarkers Consortium would provide a framework wherein laboratories studying the selected technologies would have access to matched preand post-treatment clinical samples from multiple clinical settings as obtained by the OBBR or an equivalent source. The samples could be from patients treated with approved therapies (e.g., the control arms of randomized clinical trials), well-annotated regarding patient characteristics and outcomes, and collected and processed according to standard protocols as described above. Fresh blood samples may be needed for these studies since archived samples may contain degraded cells and no longer reflect the disease state of the donor at the time of collection. The samples could be analyzed by multiple methods, would be blinded to the analyzing laboratory, and results data would be compiled by the CWG prior to release back to the assay developer. This approach would yield information regarding whether different technologies are detecting different CTC populations and provide information for definitions of analytically valid biomarkers that may need to be established for these different populations. 


\section{Clinical trial design considerations}

Despite the fact that research aimed at defining and understanding the biology of CTCs is still ongoing and many promising assays are still early in development, the Workshop participants and CWG believe that it is crucial to establish clinical validation and qualification trials soon with the goal of determining the true clinical relevance of CTCs and specific assays of CTCs. In this regard, the excellent on-going qualification work in collaboration with FDA regarding the use of CTCs as an efficacy response surrogate biomarker for survival in patients with advanced prostate cancer $[38,43]$ was acknowledged.

Beyond clinical validation of specific assays, CTC qualification studies should initially seek to answer clinically relevant questions, such as a) to determine the potential utility of CTCs in early clinical development of drugs (phase 1 and 2 trials); b) to determine if enumeration could be an early efficacy response marker; c) to help drive the use of enumeration as a surrogate marker of response to therapy; d) to investigate whether CTC evaluations could augment or replace imaging for response monitoring; and e) to investigate whether the molecular analysis of CTCs could replace tumor biopsies for patient stratification for targeted therapies. In the short term, there is general interest in the application of CTC enumeration for determining response to therapy; therefore, association of CTC measurements with complete response, partial response, stable disease, and progressive disease would be appropriate endpoints for initial clinical trials.

Several trial designs may be useful in addressing these questions regarding evaluation of clinical validity of CTC technologies and qualification of CTC measurements as biomarkers of response to therapy. First, CTC substudies may be added to ongoing trials where the study treatment choices and primary endpoints (early endpoints such as objective response, as well as clinical outcomes) would be dictated by the parent trial. Singlearm studies could be used to explore changes pre- and post-therapy and correlation with outcomes, thus assisting with determining cut points. As single-arm trials can only evaluate prognostic potential, two-arm, two-drug substudies could also be used to compare results with different therapies to evaluate the predictive potential of CTCs. Alternatively, the CTC study may be fully integrated into the trial design. In this design, patients would be randomized on the basis of the presence or absence of CTCs. The FDA has recommended this study design to evaluate diagnostic tests for use in the selection of drug therapy.

One example of an ongoing clinical trial to test the clinical utility of CTCs is SWOG S0500. In this trial, women starting a first line chemotherapeutic regimen for hormone-refractory metastatic breast cancer and who have persistently elevated CTCs after one cycle are randomly assigned to continue their therapy until classic evidence of progression (history, physical examination, imaging) or to change immediately to a different regimen. The goal of this study is to demonstrate an improved overall survival for women who are switched, based on a CTC test result (see Figure 1) [64], from an apparently ineffective treatment strategy to an alternative one. Patient populations where treatments have the potential to change based on the results of the trial should be targeted. The cohorts should include patients with measureable, advanced, non-hematologic cancers, as currently the most interesting and appropriate clinical application of CTC analysis is to establish its predictive value for response to therapy.

In terms of study indication, there should be no bias for target tumors other than the robustness of the available data. Robust CTC data have been obtained with the CellSearch $^{\text {ma }}$ System for breast, colorectal, and prostate disease. With the same technology, low numbers of CTCs are captured in the metastatic settings for colon and lung cancer; therefore, newer technologies with higher sensitivity and good specificity rates may be useful in these settings. In early disease, such as neoadjuvant settings, where fewer CTCs are expected $[8,9,65]$, a potential benefit of more sensitive assays could be a shorter timeframe to analysis of study endpoints like the extent of residual disease after surgery as an early marker of outcome, which provides value for new drug development. In addition to more efficient enumeration, newer technologies provide the promise of molecular profiling of tumor response to therapy in all the clinical designs described.

\section{A clinical validation and qualification study strategy and process}

The CSC of the Biomarkers Consortium is interested in supporting a series of studies to help resolve important pre-competitive issues around CTCs, with the overall objectives of providing evidence toward qualification of CTC derived biomarkers for assessing prognosis pretherapy, establishing CTC number as a surrogate for survival, and determining whether the molecular profile of CTCs predict response to treatment.

The initial goal of the proposed strategy will be to demonstrate the robustness of candidate CTC assay technologies currently under development, prior to clinical studies, in order to determine which of the platforms are closest to being ready for validation in the clinical trial setting. The proposed studies will evaluate newer CTC enumeration assays considered to be the most promising technologies using criteria created by the CSC and CWG against the FDA-cleared analytically valid CellSearch ${ }^{\mathrm{m}}$ assay. The most promising CTC 


\section{SCHEMA}

Registration

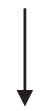

*Screening blood draw prior to first dose of first-line chemotherapy

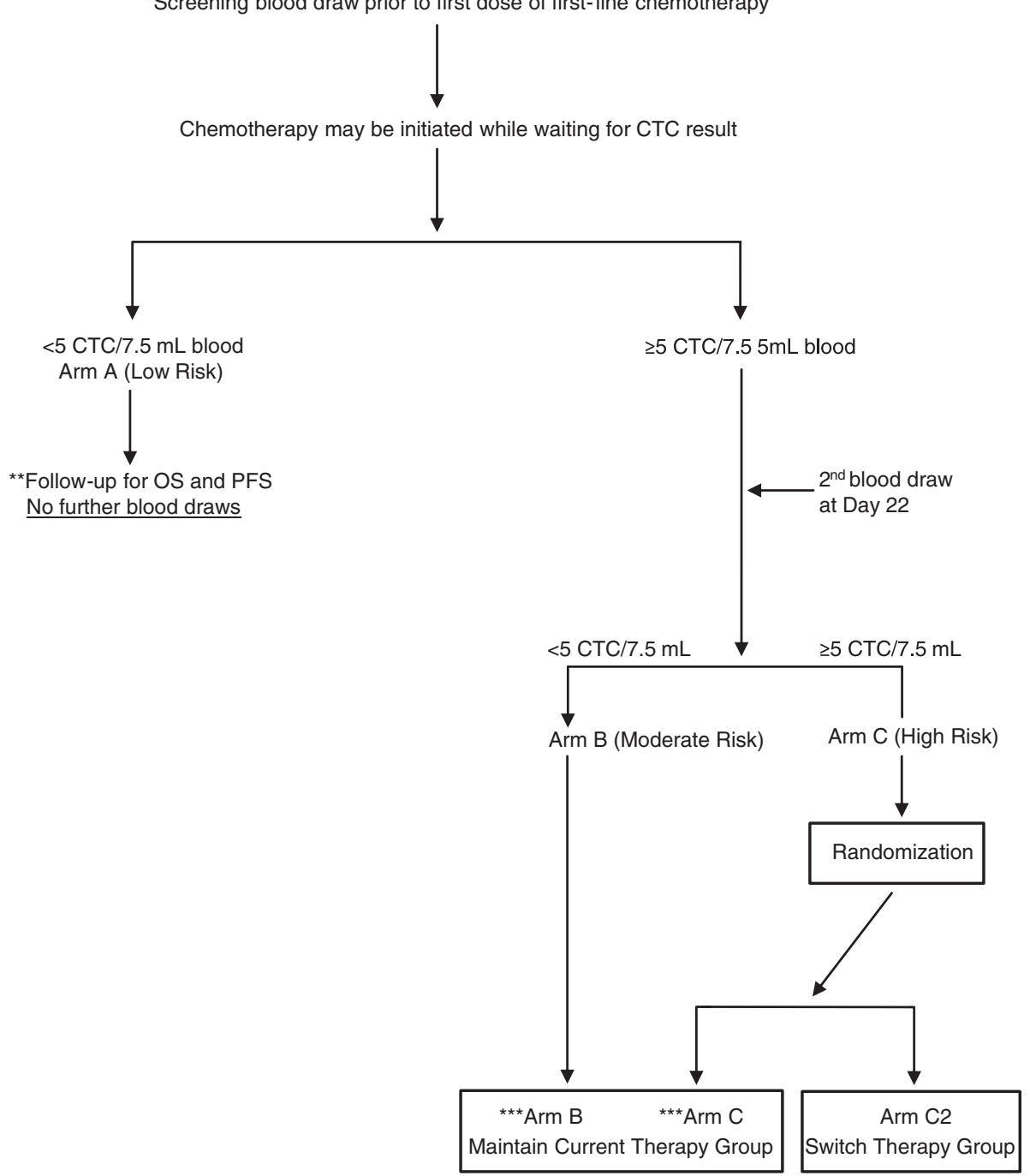

* Patients must be registered prior to initiation of testing (no more than one working day prior to initial CTC submission).

** Patients in the Low Risk Group (Arm A) may enroll in other clinical trials while being followed for OS and PFS on S0500.

*** Patients in Arms B and C1 and their physicians will be blinded to which arm they are by study design. Protocol requirements are the same for these two arms.

Figure 1 Schema of Southwest Oncology Group (SWOG) Study S0500. This clinical study is evaluating the use of CTC levels in managing the treatment of metastatic breast cancer patients. Baseline CTC levels are determined using the CellSearch System ${ }^{\text {TM }}$. Patients with CTC levels $<5$ CTCs/7.5 ml receive no further therapy, but are followed for progression-free survival (PFS) and overall survival (OS) (Arm A). For the remaining patients ( $\geq 5 \mathrm{CTCs} / 7.5 \mathrm{ml}$ blood), CTCs are measured at specified time points during the course of chemotherapy. Patients with $<5 \mathrm{CTCs} / 7.5 \mathrm{ml}$ blood at 22 weeks continue with their current chemotherapy (Arm B). Patients with $\geq 5 \mathrm{CTCs} / 7.5 \mathrm{ml}$ blood at this time point are randomized to current therapy (Arm C1) or a different therapy (Arm C2). Patients are followed for PFS and OS. (Reprinted by permission from the American Association for Cancer Research: Hayes DF, Smerage J: Is there a role for circulating tumor cells in the management of breast cancer? Clin Cancer Res 2008, 14 (12):3646-3650 DOI:10.1158/1078-0432.CCR-07-4481. See reference [64]). 
molecular characterization assays will also be compared using these criteria. Additionally, recognizing the need for standardizing procedures for specimen collection and processing to ensure the reliability of CTC measurements, the CWG will develop these procedures for CTC assays evaluated in this project. A small pilot in this regard was recently presented at an OBBR symposium, where CSSI, Offices of Physical Sciences-Oncology (OPSO), and OBBR are collaborating to examine the potential of using high-content systems to measure the effect of pre-analytical variables on biophysical parameters associated with biospecimens.

For cell spiking experiments, cell lines considered appropriate for the selected technologies will be obtained and cultured in standard conditions. Fluorescent labelling of target cells will be performed using standard cell labelling kits. Multiple samples from a given cell suspension will be counted and averaged to produce a mean cell count with a small standard deviation in order to minimize counting errors. The cell suspensions will then be appropriately diluted and processed using the selected CTC assay technologies. Capture efficiency percentages will be calculated using criteria as defined by the CWG.

In clinical studies, triplicate specimens will be collected from subjects participating in ongoing studies with relevant indications and study populations in order to compare the candidate assays against each other. For the CTC enumeration studies, one of each set of three samples will be analyzed using the CellSearch ${ }^{\mathrm{mix}}$ assay. Similarly, for the CTC molecular characterization studies, one assay will be selected to be used as the anchor. All clinical samples will be procured through the OBBR, or using SOPs compliant with OBBR requirements.

In the clinical validation studies, CTC substudies will be conducted in prospective phase 2 or 3 clinical trials (or if the assays selected do not require fresh blood, archived samples will be accessed from completed prospective studies for retrospective analysis) in an attempt to correlate CTC measurements with clinical outcomes related to treatment response, and time-related outcomes such as time to progression or disease-free survival. Here, duplicate specimens will be collected. The CTC assays will be performed pre-therapy and at defined intervals post-therapy on anonymized patient samples collected in the trial, blinding technicians to any patient identifiers. The specimens will be collected at participating sites and forwarded to the specified clinical laboratories for processing. In addition to SOPs for variables associated with sample collection as outlined above standard protocols are needed to allow comparison of CTC assay results across technology platforms. Just as challenging is the development of standards for collecting certain data points to analyze after advances have occurred in the field, so comparisons could be made over time. The standards would have to be flexible to easily incorporate new technologies.

After performing clinical validation studies, the next stage, qualification, would be follow-on clinical studies to determine the context-of-use of specific CTC measures. These studies will most likely be conducted in the phase 3 metastatic disease trial setting for specified indications in specified study populations. Baseline CTCs would be assessed, and then additional assessments would be made at some point after the start of treatment. These assessments may be used to determine the role of CTC analysis for monitoring disease recurrence, evaluating new treatments against standard therapy, or investigating concordance between imaging and CTC analysis. If a series of studies with clinical benefit outcomes shows good correlation and reproducibility between a given CTC measure and survival, that biomarker could be considered a candidate for FDA qualification.

\section{Conclusions}

Without question, the Veridex CellSearch ${ }^{\mathrm{Tw}}$ assay and the advanced technologies now being applied to CTC detection and analysis have high promise for providing biomarkers and biomarker assays useful in oncological drug development, monitoring the course of disease in cancer patients, and in understanding the biology of cancer progression. However, many questions remain unanswered regarding the biology of CTCs, best methods for their enumeration and characterization, and the path to regulatory and general clinical acceptance for technologies currently under development. Standard protocols for acquisition and processing of blood samples, as well as sources of well-annotated clinical samples (including clinical outcomes) and application of criteria for analytical and clinical validation of CTC assays and qualification of CTC-based biomarkers are mandatory for the next steps in evaluation of these technologies. Developing and applying these standards is difficult, if not impossible, for individual research institutions and companies; this effort requires coordinated clinical trial resources for obtaining samples and infrastructure for developing standards, managing the collection and distribution of samples, and evaluation of test results, as well as input from engaged scientists and the FDA. To this end, the Biomarkers Consortium, as a public-private partnership, is proposing and planning to implement the framework described in this review.

\section{Abbreviations}

BLA: Biologics license application; CDER: Center for Drug Evaluation and Research; CDRH: Center for Devices and Radiological Health; CK: Cytokeratin; CLIA: Clinical laboratory improvement amendments; CLSI: Clinical and Laboratory Standards Institute; CSC: Cancer Steering Committee; CSSI: NCI Center for Strategic Scientific Initiatives; CTC: Circulating tumor cell; CWG: CTC working group; DAPI: 4,6-diamidino-2-phenylindole;

DEP: Dielectrophoretic; DFFF: Dielectrophoretic field flow fractionation; 
EMT: Epithelial-mesenchymal transition; EORTC: European Organisation for Research and Treatment of Cancer; FDA: US Food \& Drug Administration; FISH: Fluorescence in situ hybridization; FNIH: Foundation for the National Institutes of Health; FSMW: Functionalized structured medical wire; GLP: Good laboratory practice; HER2: Human epidermal growth factor receptor 2; IND: Investigational new drug application; NCI: US National Cancer Institute; NDA: New drug application; OBBR: NCl Office of Biorepositories and Biospecimen Research; OPSO: NCI Office of Physical Sciences-Oncology; PCR: Polymerase chain reaction; PSMA: Prostate specific membrane antigen; RT-PCR: Reverse transcriptase-polymerase chain reaction; SOPs: Standard operating procedures.

\section{Competing interests}

Several of the authors are past or current employees of, stockholders in, consultants to, or have received research funding or honoraria from Veridex LLC, the manufacturer of the CellSearch System ${ }^{\text {TM }}$ for detection of CTCs, or its parent company Johnson \& Johnson (ND, DH, MCL, RM, KP, HS). DH has also been a consultant to Biomarker Strategies of Baltimore, Maryland on CTCS and is named as an inventor or co-inventor on patents on applying CTCs in clinical settings. MC is a consultant to Alere, Inc. on CTCs; GK is an employee and stockholder of Covance, Inc., which includes CTC assays (particularly the Veridex CellSearch ${ }^{T M}$ system) among its commercial offerings; and DP has been an employee of Nodality, Inc. which is developing technology that has potential application in CTC analysis. The remaining authors have no relevant competing interests (CC, BGP, AD, GJK, PK, JL, SM, LN, SPW, EP, LR, AS, CCS).

\section{Authors' contributions}

All authors contributed to the scientific and technical material presented in the manuscript, either by providing information based on direct experience with CTC technologies or relevant experience in developing biomarkers for clinical use. DP, co-chair of the Biomarkers Consortium CSC and of the CWG, led overall development of the manuscript. GJK, co-chair of the Biomarkers Consortium CSC, ensured that aspects of CTC science relevant to development of CTCs as biomarkers for predictive and prognostic applications in oncologic development were incorporated in the manuscript. BGP and CCS were responsible for background research and drafting the manuscript. Note that the contributions of $A D$ to this manuscript are from his perspective and do not necessarily represent the views of the FDA. All authors read and approved the final manuscript.

\section{Authors' information}

As noted above, each author contributed direct experience in the development of drugs or biomarkers, development and application of CTC technologies, or both.

\section{Acknowledgements}

The authors would like to acknowledge discussions with other members of the CSC, developers of new CTC assays, and attendees at the CTC Workshop in 2010 as contributions to this manuscript. The authors are grateful to the Biomarkers Consortium and especially its Director, David Wholley for support of the CTC project and to Dr. J. Milburn Jessup of $\mathrm{NCl}$ and Drs. Elizabeth Mansfield and Robert Becker of the FDA for review of this manuscript. The authors thank Barbara Gress for literature research and Lora Smith and Susan Thompson for editorial assistance in completing the manuscript.

\section{Author details}

${ }^{1}$ New Enterprise Associates, Menlo Park, CA 94025, USA. ${ }^{2}$ Johnson \&Johnson, Radnor, PA 19087, USA. ${ }^{3}$ CCS Associates, Mountain View, CA 94043, USA. ${ }^{4}$ Critical Path Institute, Tucson, AZ 85718, USA. ${ }^{5}$ Fox Chase Cancer Center, Philadelphia, PA 19111, USA. ${ }^{6}$ Center for Drug Evaluation Research, US Food \& Drug Administration, Silver Spring, MA 20903, USA. 'University of Michigan, Ann Arbor, MI 48109, USA. ${ }^{8}$ Covance Genomic Lab, Covance Central Labs, Seattle, WA 98382, USA. 'Daiichi-Sankyo Pharma Development, Edison, NJ 08837, USA. ${ }^{10}$ National Cancer Institute, Bethesda, MA 20892, USA.

${ }^{11}$ Georgetown University, Washington, DC 20007, USA. ${ }^{12}$ Veridex, LLC, Raritan, NJ 08869, USA. ${ }^{13}$ EMD Serono, Rockland, MA 02370, USA. ${ }^{14}$ University Medical Center Hamburg-Eppendorf, 20246, Hamburg, Germany.

${ }^{15}$ Foundation for the National Institutes of Health, Bethesda, MA 20814, USA. ${ }^{16}$ Genentech, South San Francisco, CA 94080, USA. ${ }^{17}$ GlaxoSmithKline, Collegeville, PA 19426, USA. ${ }^{18}$ Eli Lilly and Company, Indianapolis, IN 46285, USA. ${ }^{19}$ Memorial Sloan-Kettering Cancer Center, New York, NY 10065, USA.
Received: 21 April 2012 Accepted: 14 June 2012

Published: 2 July 2012

\section{References}

1. Yu M, Stott S, Toner M, Maheswaran S, Haber DA: Circulating tumor cells: approaches to isolation and characterization. J Cell Biol 2011, 192:373-382.

2. Nelson NJ: Circulating tumor cells: will they be clinically useful? J Natl Cancer Inst 2010, 102:146-148.

3. Hou JM, Krebs M, Ward T, Morris K, Sloane R, Blackhall F, Dive C: Circulating tumor cells, enumeration and beyond. Cancers 2010, 2:1236-1250.

4. Nagrath S, Stott SL, Lee RJ, Yu M, Ulkus LL, lafrate JA, Smith MR, Tompkins RG, Sequist LV, Haber DA, Maheswaran S, Toner M: Detection and characterization of circulating tumor cells in localized and metastatic prostate cancer patients using CTC-Chip microfluidic technology. Proc Am Assoc Cancer Res 2010, 101st:abstr 1136.

5. Bertolin M, Pigozzo J, Koussis H, Ghiotto C, Valente S, Michieletto S, Magro C, Rossi E, Zamarchi R, Bozza F, Jirillo A, Chiarion-Sileni V, Amadori A: Circulating tumor cells detection and evaluation of their apoptotic status in patients with localized breast cancer before and after surgery. J Clin Oncol 2011, 29(suppl):abstr e21127.

6. Muller V, Stahmann N, Riethdorf S, Rau T, Zabel T, Goetz A, Janicke F, Pantel $\mathrm{K}$ : Circulating tumor cells in breast cancer: correlation to bone marrow micrometastases, heterogeneous response to systemic therapy and low proliferative activity. Clin Cancer Res 2005, 11:3678-3685.

7. Nagrath S, Sequist LV, Maheswaran S, Bell DW, Irimia D, Ulkus L, Smith MR, Kwak EL, Digumarthy S, Muzikansky A, Ryan P, Balis UJ, Tompkins RG, Haber DA, Toner M: Isolation of rare circulating tumour cells in cancer patients by microchip technology. Nature 2007, 450:1235-1239.

8. Pierga JY, Bidard FC, Mathiot C, Brain E, Delaloge S, Giachetti S, de Cremoux P, Salmon R, Vincent-Salomon A, Marty M: Circulating tumor cell detection predicts early metastatic relapse after neoadjuvant chemotherapy in large operable and locally advanced breast cancer in a phase II randomized trial. Clin Cancer Res 2008, 14:7004-7010.

9. Riethdorf S, Muller V, Zhang L, Rau T, Loibl S, Komor M, Roller M, Huober J, Fehm T, Schrader I, Hilfrich J, Holms F, Tesch H, Eidtmann H, Untch M, von Minckwitz G, Pantel K: Detection and HER2 expression of circulating tumor cells: prospective monitoring in breast cancer patients treated in the neoadjuvant GeparQuattro trial. Clin Cancer Res 2010, 16:2634-2645.

10. Xenidis N, Ignatiadis M, Apostolaki S, Perraki M, Kalbakis K, Agelaki S, Stathopoulos EN, Chlouverakis G, Lianidou E, Kakolyris S, Georgoulias V, Mavroudis D: Cytokeratin-19 mRNA-positive circulating tumor cells after adjuvant chemotherapy in patients with early breast cancer. J Clin Oncol 2009, 27:2177-2184

11. Rhim AD, Mirek ET, Aiello NM, Maitra A, Bailey JM, McAllister F, Reichert M, Beatty GL, Rustgi AK, Vonderheide RH, Leach SD, Stanger BZ: EMT and dissemination precede pancreatic tumor formation. Cell 2012, 148:349-361.

12. Aktas B, Tewes M, Fehm T, Hauch S, Kimmig R, Kasimir-Bauer S: Stem cell and epithelial-mesenchymal transition markers are frequently overexpressed in circulating tumor cells of metastatic breast cancer patients. Breast Cancer Res 2009, 11:R46.

13. Polyak K, Weinberg RA: Transitions between epithelial and mesenchymal states: acquisition of malignant and stem cell traits. Nat Rev Cancer 2009, 9:265-273.

14. Bednarz N, Eltze E, Semjonow A, Rink M, Andreas A, Mulder L, Hannemann J, Fisch M, Pantel K, Weier HU, Bielawski KP, Brandt B: BRCA1 loss preexisting in small subpopulations of prostate cancer is associated with advanced disease and metastatic spread to lymph nodes and peripheral blood. Clin Cancer Res 2010, 16:3340-3348.

15. Joosse SA, Hannemann J, Spotter J, Bauche A, Andreas A, Muller V, Pantel K: Changes in keratin expression during metastatic progression of breast cancer: impact on the detection of circulating tumor cells. Clin Cancer Res 2012, 18:993-1003.

16. Lilly B, Kennard S: Differential gene expression in a coculture model of angiogenesis reveals modulation of select pathways and a role for Notch signaling. Physiol Genomics 2009, 36:69-78.

17. Stott SL, Hsu CH, Tsukrov DI, Yu M, Miyamoto DT, Waltman BA, Rothenberg SM, Shah AM, Smas ME, Korir GK, Floyd FP Jr, Gilman AJ, Lord JB, Winokur D, Springer S, Irimia D, Nagrath S, Sequist LV, Lee RJ, Isselbacher KJ, Maheswaran S, Haber DA: Toner M: Isolation of circulating tumor cells 
using a microvortex-generating herringbone-chip. Proc Natl Acad Sci U S A 2010, 107:18392-18397.

18. Hou JM, Krebs M, Ward T, Sloane R, Priest L, Hughes A, Clack G, Ranson M, Blackhall F, Dive C: Circulating tumor cells as a window on metastasis biology in lung cancer. Am J Pathol 2011, 178:989-996.

19. Hou JM, Krebs MG, Lancashire L, Sloane R, Backen A, Swain RK, Priest LJ, Greystoke A, Zhou C, Morris K, Ward T, Blackhall FH, Dive C: Clinical significance and molecular characteristics of circulating tumor cells and circulating tumor microemboli in patients with small-cell lung cancer. $J$ Clin Oncol 2012, 30:525-532.

20. Molnar B, Ladanyi A, Tanko L, Sreter L, Tulassay Z: Circulating tumor cell clusters in the peripheral blood of colorectal cancer patients. Clin Cancer Res 2001, 7:4080-4085.

21. Serrano Fernadez MJ, Alvarez Merino JC, Martinez Zubiaurre I, Fernandez Garcia A, Sanchez Rovira P, Lorente Acosta JA: Clinical relevance associated to the analysis of circulating tumor cells in patients with solid tumors. Clin Transl Oncol 2009, 11:668-659.

22. Wang ZP, Eisenberger MA, Carducci MA, Partin AW, Scher HI, Ts'O PO: Identification and characterization of circulating prostate carcinoma cells. Cancer 2000, 88:2787-2795.

23. Glinsky VV, Glinsky GV, Glinskii OV, Huxley VH, Turk JR, Mossine W Deutscher SL, Pienta KJ, Quinn TP: Intravascular metastatic cancer cell homotypic aggregation at the sites of primary attachment to the endothelium. Cancer Res 2003, 63:3805-3811.

24. Pantel K, Deneve E, Nocca D, Coffy A, Vendrell JP, Maudelonde T, Riethdorf S, Alix-Panabieres C: Circulating epithelial cells in patients with benign colon diseases. Clin Chem 2012, 58:936-940

25. Riethdorf S, Fritsche H, Muller V, Rau T, Schindlbeck C, Rack B, Janni W, Coith C, Beck K, Janicke F, Jackson S, Gornet T, Cristofanilli M, Pantel K: Detection of circulating tumor cells in peripheral blood of patients with metastatic breast cancer: a validation study of the CellSearch system. Clin Cancer Res 2007, 13:920-928.

26. Meng S, Tripathy D, Shete S, Ashfaq R, Haley B, Perkins S, Beitsch P, Khan A Euhus D, Osborne C, Frenkel E, Hoover S, Leitch M, Clifford E, Vitetta E, Morrison L, Herlyn D, Terstappen LW, Fleming T, Fehm T, Tucker T, Lane N, Wang J, Uhr J: HER-2 gene amplification can be acquired as breast cancer progresses. Proc Natl Acad Sci U S A 2004, 101:9393-9398.

27. Wulfing P, Borchard J, Buerger H, Heidl S, Zanker KS, Kiesel L, Brandt B: HER2-positive circulating tumor cells indicate poor clinical outcome in stage I to III breast cancer patients. Clin Cancer Res 2006, 12:1715-1720.

28. Chang HJ, Han SW, Oh DY, Im SA, Jeon YK, Park IA, Han W, Noh DY, Bang YJ, Kim TY: Discordant human epidermal growth factor receptor 2 and hormone receptor status in primary and metastatic breast cancer and response to trastuzumab. Jpn J Clin Oncol 2011, 41:593-599.

29. Alix-Panabieres $C$, Schwarzenbach $H$, Pantel K: Circulating tumor cells and circulating tumor DNA. Annu Rev Med 2012, 63:199-215.

30. Wang LH, Pfister TD, Parchment RE, Kummar S, Rubinstein L, Evrard YA, Gutierrez ME, Murgo AJ, Tomaszewski JE, Doroshow JH, Kinders RJ: Monitoring drug-induced gammaH2AX as a pharmacodynamic biomarker in individual circulating tumor cells. Clin Cancer Res 2010, 16:1073-1084.

31. Maheswaran S, Haber DA: Circulating tumor cells: a window into cancer biology and metastasis. Curr Opin Genet Dev 2010, 20:96-99.

32. Lianidou ES, Markou A: Circulating tumor cells in breast cancer: detection systems, molecular characterization, and future challenges. Clin Chem 2011, 57:1242-1255

33. Ignatiadis M, Rothe F, Chaboteaux C, Durbecq V, Rouas G, Criscitiello C, Metallo J, Kheddoumi N, Singhal SK, Michiels S, Veys I, Rossari J, Larsimont D, Carly B, Pestrin M, Bessi S, Buxant F, Liebens F, Piccart M, Sotiriou C: HER2-positive circulating tumor cells in breast cancer. PLOS One 2011 6:e15624.

34. US Food and Drug Administration: Guidance for Industry: Qualification Process for Drug Development Tools. Draft Guidance; 2010. http://www.fda. gov/downloads/Drugs/GuidanceComplianceRegulatorylnformation/ Guidances/UCM230597.pdf;2010.

35. US Food and Drug Administration: Guidance for Industry: Pharmacogenomic Data Submissions, http://www.fda.gov/downloads/Regulatorylnformation/ Guidances/ucm126957.pdf; 2005.

36. US Food and Drug Administration: Draft Guidance for Industry and Food and Drug Administration Staff: In Vitro Companion Diagnostic Devices Draft Guidance; 2011. http://www.fda.gov/downloads/MedicalDevices/ DeviceRegulationandGuidance/GuidanceDocuments/UCM262327.pdf;2011.
37. MCShane LM, Altman DG, Sauerbrei W, Taube SE, Gion M, Clark GM: Reporting recommendations for tumor marker prognostic studies (REMARK). J Natl Cancer Inst 2005, 97:1180-1184.

38. Shaffer DR, Leversha MA, Danila DC, Lin O, Gonzalez-Espinoza R, Gu B, Anand A, Smith K, Maslak P, Doyle GV, Terstappen LW, Lilja H, Heller G, Fleisher M, Scher HI: Circulating tumor cell analysis in patients with progressive castration-resistant prostate cancer. Clin Cancer Res 2007, 13:2023-2029.

39. Serrano MJ, Sanchez-Rovira P, Delgado-Rodriguez M, Gaforio JJ: Detection of circulating tumor cells in the context of treatment: prognostic value in breast cancer. Cancer Biol Ther 2009, 8:671-675.

40. Danila DC, Anand A, Sung CC, Heller G, Leversha MA, Cao L, Lilja H, Molina A, Sawyers CL, Fleisher M, Scher HI: TMPRSS2-ERG status in circulating tumor cells as a predictive biomarker of sensitivity in castration-resistant prostate cancer patients treated with abiraterone acetate. Eur Urol 2011, 60:897-904.

41. Fehm T, Muller V, Aktas B, Janni W, Schneeweiss A, Stickeler E, Lattrich C, Lohberg CR, Solomayer E, Rack B, Riethdorf S, Klein C, Schindlbeck C, Brocker K, Kasimir-Bauer S, Wallwiener D, Pantel K: HER2 status of circulating tumor cells in patients with metastatic breast cancer: a prospective, multicenter trial. Breast Cancer Res Treat 2010, 124:403-412.

42. Cristofanilli M, Budd GT, Ellis MJ, Stopeck A, Matera J, Miller MC, Reuben JM, Doyle GV, Allard WJ, Terstappen LW, Hayes DF: Circulating tumor cells, disease progression, and survival in metastatic breast cancer. $N$ Engl J Med 2004, 351:781-791.

43. de Bono JS, Scher HI, Montgomery RB, Parker C, Miller MC, Tissing H, Doyle GV, Terstappen LW, Pienta KJ, Raghavan D: Circulating tumor cells predict survival benefit from treatment in metastatic castration-resistant prostate cancer. Clin Cancer Res 2008, 14:6302-6309.

44. Cohen SJ, Punt CJ, lannotti N, Saidman BH, Sabbath KD, Gabrail NY, Picus J, Morse M, Mitchell E, Miller MC, Doyle GV, Tissing H, Terstappen LW, Meropol NJ: Relationship of circulating tumor cells to tumor response, progression-free survival, and overall survival in patients with metastatic colorectal cancer. J Clin Oncol 2008, 26:3213-3221.

45. Rink M, Chun FK, Dahlem R, Soave A, Minner S, Hansen J, Stoupiec M, Coith C, Kluth LA, Ahyai SA, Friedrich MG, Shariat SF, Fisch M, Pantel K, Riethdorf S: Prognostic role and HER2 expression of circulating tumor cells in peripheral blood of patients prior to radical cystectomy: a prospective study. Eur Urol 2012, 61:810-817.

46. Naoe M, Ogawa Y, Morita J, Omori K, Takeshita K, Shichijyo T, Okumura T, Igarashi A, Yanaihara A, Iwamoto S, Fukagai T, Miyazaki A, Yoshida H: Detection of circulating urothelial cancer cells in the blood using the Cell Search System. Cancer 2007, 109:1439-1445.

47. Okumura Y, Tanaka F, Yoneda K, Hashimoto M, Takuwa T, Kondo N, Hasegawa S: Circulating tumor cells in pulmonary venous blood of primary lung cancer patients. Ann Thorac Surg 2009, 87:1669-1675.

48. Steen S, Nemunaitis J, Fisher T, Kuhn J: Circulating tumor cells in melanoma: a review of the literature and description of a novel technique. Proc (Bayl Univ Med Cent) 2008, 21:127-132.

49. Gradilone A, Naso G, Raimondi C, Cortesi E, Gandini O, Vincenzi B, Saltarelli R, Chiapparino E, Spremberg F, Cristofanilli M, Frati L, Aglianò AM, Gazzaniga $P$ : Circulating tumor cells (CTCS) in metastatic breast cancer (MBC): prognosis, drug resistance and phenotypic characterization. Ann Oncol 2011, 22:86-92.

50. Pantel K, Brakenhoff $\mathrm{RH}$, Brandt $\mathrm{B}$ : Detection, clinical relevance and specific biological properties of disseminating tumour cells. Nat Rev Cancer 2008, 8:329-340.

51. Meng S, Tripathy D, Shete $S$, Ashfaq R, Saboorian H, Haley B, Frenkel E, Euhus D, Leitch M, Osborne C, Clifford E, Perkins S, Beitsch P, Khan A, Morrison L, Herlyn D, Terstappen LW, Lane N, Wang J, Uhr J: uPAR and HER-2 gene status in individual breast cancer cells from blood and tissues. Proc Natl Acad Sci U S A 2006, 103:17361-17365.

52. Maheswaran S, Sequist LV, Nagrath $S$, Ulkus L, Brannigan B, Collura CV, Inserra E, Diederichs S, lafrate AJ, Bell DW, Digumarthy S, Muzikansky A, Irimia D, Settleman J, Tompkins RG, Lynch TJ, Toner M, Haber DA: Detection of mutations in EGFR in circulating lung-cancer cells. N Engl J Med 2008, 359:366-377.

53. Bidard FC, Mathiot C, Degeorges A, Etienne-Grimaldi MC, Delva R, Pivot $X$, Veyret C, Bergougnoux L, de Cremoux P, Milano G, Pierga JY: Clinical value of circulating endothelial cells and circulating tumor cells in metastatic breast cancer patients treated first line with bevacizumab and chemotherapy. Ann Oncol 2010, 21:1765-1771. 
54. Budd GT, Cristofanilli M, Ellis MJ, Stopeck A, Borden E, Miller MC, Matera J, Repollet M, Doyle GV, Terstappen LW, Hayes DF: Circulating tumor cells versus imaging-predicting overall survival in metastatic breast cancer. Clin Cancer Res 2006, 12:6403-6409.

55. Allan AL, Keeney M: Circulating tumor cell analysis: technical and statistical onsiderations for application to the clinic. J Oncol 2010, 2010:426218.

56. Adams AA, Okagbare PI, Feng J, Hupert ML, Patterson D, Göttert J, McCarley RL, Nikitopoulos D, Murphy MC, Soper SA: Highly efficient circulating tumor cell isolation from whole blood and label-free enumeration using polymer-based microfluidics with an integrated conductivity sensor. J Am Chem Soc 2008, 130:8633-8641.

57. Kirby BJ, Jodari M, Loftus MS, Gakhar G, Pratt ED, Chanel-Vos C, Gleghorn JP, Santana SM, Liu H, Smith JP, Navarro NV, Tagawa ST, Bander NH, Nanus DM, Giannakakou P: Functional characterization of circulating tumor cells with a prostate-cancer-specific microfluidic device. PLoS One 2012, 7:e35976. Epub 32012 Apr 35927.

58. Dancey JE, Dobbin KK, Groshen S, Jessup JM, Hruszkewycz AH, Koehler M, Parchment R, Ratain MJ, Shankar LK, Stadler WM, True LD, Gravell A, Grever MR: Biomarkers Task Force of the NCl Investigational Drug Steering Committee: Guidelines for the development and incorporation of biomarker studies in early clinical trials of novel agents. Clin Cancer Res 2010, 16:1745-1755.

59. Allard WJ, Matera J, Miller MC, Repollet M, Connelly MC, Rao C, Tibbe AG, Uhr JW, Terstappen LW: Tumor cells circulate in the peripheral blood of all major carcinomas but not in healthy subjects or patients with nonmalignant diseases. Clin Cancer Res 2004, 10:6897-6904.

60. Meng S, Tripathy D, Frenkel EP, Shete S, Naftalis EZ, Huth JF, Beitsch PD, Leitch M, Hoover S, Euhus D, Haley B, Morrison L, Fleming TP, Herlyn D, Terstappen LW, Fehm T, Tucker TF, Lane N, Wang J, Uhr JW: Circulating tumor cells in patients with breast cancer dormancy. Clin Cancer Res 2004, 10:8152-8162.

61. Smerage JB, Doyle GV, Budd GT, Schott AF, Blayney DW, Wicha MS, Repollet M, Terstappen LW, Hayes DF: The detection of apoptosis and Bcl-2 expression in circulating tumor cells (CTCs) from women being treated for metastatic breast cancer. Proc Am Assoc Cancer Res 2006, 47:abstr 792

62. Taube SE, Clark GM, Dancey JE, McShane LM, Sigman CC, Gutman SI: A perspective on challenges and issues in biomarker development and drug and biomarker codevelopment. J Natl Cancer Inst 2009, 101:1453-1463.

63. Lianidou ES: Circulating tumor cells--new challenges ahead. Clin Chem 2012, 58:805-807.

64. Hayes DF, Smerage J: Is there a role for circulating tumor cells in the management of breast cancer? Clin Cancer Res 2008, 14:3646-3650.

65. Reyal F, Valet F, de Cremoux P, Mathiot C, Decraene C, Asselain B, Brain E, Delaloge S, Giacchetti S, Marty M, Pierga JY, Bidard FC: Circulating tumor cell detection and transcriptomic profiles in early breast cancer patients. Ann Oncol 2011, 22:1458-1459.

doi:10.1186/1479-5876-10-138

Cite this article as: Parkinson et al:: Considerations in the development of circulating tumor cell technology for clinical use. Journal of

Translational Medicine 2012 10:138.

\section{Submit your next manuscript to BioMed Central and take full advantage of:}

- Convenient online submission

- Thorough peer review

- No space constraints or color figure charges

- Immediate publication on acceptance

- Inclusion in PubMed, CAS, Scopus and Google Scholar

- Research which is freely available for redistribution 